\title{
Peningkatan Keterampilan Komunikasi Guru Dalam Proses Pembelajaran Melalui Kegiatan Focus Group Discussion (FGD) Di SD Negeri 06 Situjuah Gadang
}

\author{
Nurma $^{1}$ \\ ${ }^{1}$ SDN 06 Situjuah Gadang, Kec. Situjuah Limo Nagari
}

\begin{abstract}
Abstratc: This research is motivated by the low communication skills of teachers in the learning process at SDN 06 Situjuah Gadang, Lima Puluh Kota. This study aims to improve teacher communication skills in the learning process through FGD activities. This type of research is action research using a qualitative approach. This research data in the form of information about the process and data on the results of actions obtained from observations, the results of teacher skills assessment, discussion and documentation. The data source is the process of implementing Focus Group Discussion (FGD) activities. The results show that there is an increase in research results from Cycle I to Cycle II, this proves that guidance through FGD activity can improve the teacher's communication skills.
\end{abstract}

Keyword: Communication, Learning Process, FGD

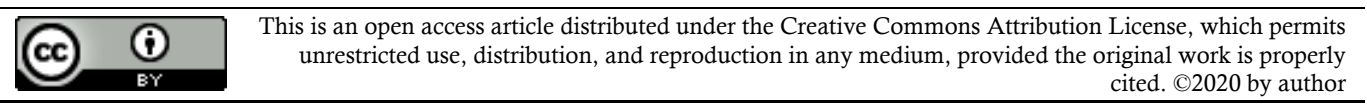

\section{PENDAHULUAN}

Guru sangat menentukan keberhasilan peserta didik, terutama dalam kaitannya dengan proses belajar mengajar dan merupakan komponen yang paling berpengaruh terhadap terciptanya proses dan hasil pendidikan yang berkualitas. Profesionalisme guru memungkinkan guru untuk memberikan pelayanan sebaik mungkin dan memaksimalkan keterampilannya, salah satunya adalah keterampilan berkomunikasi yang baik dengan siswa. Keterampilan komunikasi yang diperlukan guru antara lain keterampilan dalam berbicara, mendengar, mengatasi hambatan komunikasi verbal, memahami komunikasi nonverbal dari murid dan mampu memecahkan konflik secara konstruktif (Djamarah 2000:14). Agar dapat berkomunikasi dengan baik, guru perlu memiliki kemampuan berbahasa yang baik. Ia perlu memiliki kekayaan bahasa dan kosa kata yang cukup banyak sebab dengan menggunakan kata-kata atau istilah lain. Guru perlu menguasai stuktur kalimat dan ejaan yang benar. Struktur kalimat dan ejaan yang salah dari guru, akan ditiru salah pula, dan dapat membingungkan. Hal yang cukup penting dalam berbasa ini, guru perlu menguasai ucapan dan ragaam bahasa yang tepat dan baik.

Guru harus bisa dan terbiasa berkomunikasi secara positif dan sekaligus menghindar dari prilaku komunikasi negatif. Cara berkomunikasi positif adalah dengan menjaga citra diri yang positif, berbicara fokus, bersikap mengajak dan bukan memerintah, ekspresi wajah ramah, nada suara rendah menyenangkan, tutur kata lembut menyejukkan, gerakan badan wajar tidak dibuatbuat (Suherman, E., 2008). Guru yang efektif menggunakan keterampilannya berkomunikasi dengan siswa, tetap kritis namun tidak berlebihan, lebih asertif daripada agresif, manipulatif ataupun pasif. Pola komunikasi yang terjadi dalam interaksi antara guru dan siswa yang efektif akan menghasilkan sebuah pemahaman antara kedua belah pihak yang akan sangat membantu dalam menyukseskan proses belajar mengajar.

Berdasarkan observasi dan wawancara dengan guru, kepala sekolah, serta siswa di SD Negeri 06 Situjuah Gadang Kabupaten Lima Puluh Kota, berkaitan dengan komunikasi pembelajaran 
yang dilakukan di dalam kelas, kemampuan guru dalam mengembangkan sikap positif dalam kegiatan pembelajaran kurang baik, dimana guru tidak memberikan kesempatan kepada siswa untuk berpendapat, jarang mengulang kembali bagian-bagian yang penting dari pendapat yang disampaikan siswa dan juga jarang memberikan pujian kepada siswa yang mampu berpendapat secara baik. Selain itu, adakalanya guru tidak mau terbuka dalam menerima pendapat maupun saran siswa, guru juga tidak mau menghargai setiap perbedaan pendapat antar siswa maupun antar guru dengan siswa. Saat mengajar guru terlihat kurang memberi penekanan dengan menunjukkan bagian-bagian penting dari materi yang disampaikannya. Terkadang guru secara tidak disadari sering mengeluarkan kata-kata yang tidak empatik misalnya "dasar murid bodoh", "kamu bandel sekali". Kata-kata tidak empatik yang sering diucapkan guru ini menimbulkan dampak yang negatif dalam diri anak didik, anak menjadi terpengaruh dan merasa dirinya betul-betul bodoh atau tidak berguna. Kata-kata tersebut mampu membentuk emosi, bahkan memunculkan reaksi nyata dari emosi atau perasaan tersebut. Respon negatif guru terlihat sangat ampuh menghancurkan iklim kelas yang kondusif dan kepribadian siswa itu sendiri.

Berdasarkan permasalahan tersebut, perlu dilakukan suatu upaya pembinaan terhadap guru salah satunya adalah melalui kegiatan diskusi kelompok. Salah satu model diskusi kelompok yang sering kali digunakan untuk memecahkan masalah secara bersama-sama adalah Fokus Group Discussion (FGD). Fokus Group Discussion (FGD) adalah bentuk diskusi yang didesain untuk memunculkan informasi mengenai keinginan, kebutuhan, sudut pandang, kepercayaan dan pengalaman yang dikehendaki peserta didik (Paramita, A., \& Kristiana, L., 2013).

\section{METODOLOGI}

Penelitian ini merupakan penelitian tindakan dengan menggunakan pendekatan kualitatif. Pada penelitian ini terdapat dua siklus dengan masing-masing siklus memiliki tiga tahapan yaitu: rencana, tindakan dan pengamatan, serta refleksi. Subjek pada peneltian ini adalah tiga orang guru SDN 06 Situjuah Gadang, Lima Puluh Kota. Data penelitian ini berupa informasi tentang proses dan data hasil tindakan yang diperoleh dari hasil pengamatan, hasil penilaian keterampilan guru, diskusi dan dokumentasi. Sumber data adalah proses pelaksanaan kegiatan Focus Group Discussion (FGD) di SD Negeri 06 Situjuah Gadang Kabupaten Lima Puluh Kota. Data yang diperoleh dalam penelitian dianalisis dengan menggunakan model analisis data kualitatif dengan menelaah sejak pengumpulan data sampai sebelum data terkumpul. Data tersebut direduksi berdasarkan masalah yang diteliti, diikuti penyajian data dan terakhir penyimpulan atau verifikasi.

\section{HASIL DAN PEMBAHASAN}

Penelitian ini merupakan penelitian tindakan yang terdiri dari dua siklus dan masing-masing siklusnya terdapat tiga tahapan, yaitu: rencana, tindakan dan pengamatan, dan refleksi.

\section{Siklus I}

A. Rencana

Perencanaan FGD untuk meningkatkan keterampilan komunikasi guru dalam proses pembelajaran disusun secara kolaboratif antara peneliti dengan kepala sekolah karena pengamatan dilakukan oleh kepala sekolah tersebut. Langkah awal yang direncanakan pada penelitian tindakan sekolah ini terdiri dari beberapa kegiatan, yakni:

- Identifikasi masalah. Peneliti mengidentifikasi kemampuan dan pemahaman guruguru dalam melakukan komunikasi pada saat proses pembelajaran berlangsung.

- Pertemuan dengan guru-guru, menginformasikan tentang pelaksanaan penelitian.

- Menyusun rancangan tindakan berupa rencana kegiatan FGD yang berkaitan dengan keterampilan komunikasi guru dalam proses pembelajaran dengan merumusan langkah-langkah kegiatan penyelesaian masalah.

- Peneliti menyiapkan skenario FGD yang akan dilaksanakan selama proses tindakan.

- Mempersiapkan instrument penelitian.

- Merumusan indikator keberhasilan penerapan FGD dalam meningkatkan keterampilan komunikasi guru dalam proses pembelajaran.

- Mengidentifikasi fasilitas yang diperlukan. Fasilitas atau alat bantu yang digunakan dalam penelitian ini. 
B. Tindakan dan Pengamatan

Pada tahap ini, peneliti memonitoring dan mengamati guru-guru dalam teknik berkomunikasi dalam proses pembelajaran. Kegiatan FGD menggunakan instrumen observasi, sesuai dengan rencana yang telah disusun sebelumnya. Pelaksanaan FGD dilakukan dengan pertemuan individual office-conference. Pelaksanaan tindakan dilakukan sebagai berikut:

- Mengamati kemampuan guru dalam melakukan komunikasi pembelajaran di kelas dan menggunakan instrument pengamatan kemampuan berkomunikasi.

- Menganalisis kemampuan guru dalam melakukan komunikasi dalam pembelajaran.

- Melakukan tes kemampuan guru melakukan komunikasi dalam pembelajaran dengan dibimbing oleh peneliti.

Selama penelitian ini berlangsung, aspek yang diamati oleh observer untuk kemampuan komunikasi, adalah sebagai berikut:

- Menggunakan bahasa yang baik

- Menggunakan bahasa yang benar

- Memilih kata yang gampang dipahami

- Memilih kata yang tepat sasaran

- Berbicara dengan tempo yang tepat

- $\quad$ Tidak menyampaikan hal-hal yang kabur

- Berpikir logis

- Berbicara untuk memotivasi kemampuan siswa yang berbicara

Dari hasi pengamatan yang telah dilakukan maka didapat hasil observasi tentang kemampuan komunikasi guru adalah sebagai berikut:

Tabel 1. Hasil Observasi Komunikasi Guru dalam Pembelajaran Siklus I

\begin{tabular}{|c|c|c|c|c|}
\hline No. & KARAKTERISTIK PENILAIAN & Skor & $\begin{array}{c}\text { Skor } \\
\text { Maksimal } \\
\end{array}$ & Kualifikasi \\
\hline 1. & Menggunakan bahasa yang baik & 3 & 4 & $\mathrm{C}$ \\
\hline 2 & Menggunakan bahasa yang benar & 3 & 4 & $\mathrm{~B}$ \\
\hline 3 & Memilih kata yang gampang dipahami & 2 & 4 & $\mathrm{C}$ \\
\hline 4 & Memilih kata yang tepat sasaran & 3 & 4 & $\mathrm{~B}$ \\
\hline 5 & Berbicara dengan tempo yang tepat & 2 & 4 & $\mathrm{C}$ \\
\hline 6 & Tidak meyampaikan hal- hal yang kabur & 2 & 4 & $\mathrm{~B}$ \\
\hline 7 & Berpikir logis & 2 & 4 & SB \\
\hline \multirow[t]{3}{*}{8} & $\begin{array}{l}\text { Berbica untuk memotivasi kemampuan siswa } \\
\text { yang berbicara }\end{array}$ & 2 & 4 & $\mathrm{~B}$ \\
\hline & Jumlah & 19 & 28 & \\
\hline & Persentase & $69 \%$ & & $\mathbf{C}$ \\
\hline
\end{tabular}

Dari hasil lembaran pengamatan dapat dilihat jumlah skor yang diperoleh dalam pelaksanaan kegiatan FGD untuk meningkatkan keterampilan komunikasi guru dalam pembelajaran pada siklus I ini adalah 19 dan skor maksimalnya 28. Dengan demikian persentase skor rata-rata adalah 69\%. Berarti aktivitas supervisor selama kegiatan Focus Group Discussion (FGD) berdasarkan hasil dari pengamatan observer berada pada kategori cukup.

Lebih lanjut, kegiatan FGD diakhiri dengan penilaian terhadap keterampilan komunikasi guru dalam proses pembelajaran. Aspek yang diamati pada penilaian ini adalah:

- Kemampuan guru mengembangkan sikap positif dalam kegiatan pembelajaran

- Kemampuan guru untuk bersikap luwes dan terbuka dalam kegiatan pembelajaran

- Kemampuan guru untuk tempil secara bersungguh-sungguh dalam kegiatan pembelajaran

- Kemampuan guru untuk mampu mengelola interaksi siswa dalam kegiatan pembelajaran

Tabel 2. Hasil Penilaian Keterampilan Komunikasi Guru Dalam Proses Pembelajaran Siklus I

\begin{tabular}{|l|l|l|l|l|}
\hline No & Nama Guru & ASPEK YANG DINILAI & Jumlah & Nilai \\
\hline
\end{tabular}




\begin{tabular}{|c|c|c|c|c|c|c|c|}
\hline & & I & II & III & IV & & \\
\hline 1 & Yesti, S.Pd & 4 & 4 & 4 & 3 & 15 & 75 \\
\hline 2 & Adri, S.Pd & 3 & 4 & 4 & 4 & 15 & 75 \\
\hline \multirow[t]{3}{*}{3} & Amrina, S.Pd.SD & 4 & 4 & 4 & 4 & 16 & 80 \\
\hline & Jumlah & & & & & & 230 \\
\hline & Rata-Rata & & & & & & 76,67 \\
\hline
\end{tabular}

Berdasarkan penilaian terhadap keterampilan komunikasi guru dalam pembelajaran yang dikemukakan tabel diatas terlihat nilai rata-rata kemampuan komunikasi guru dalam pembelajaran baru mencapai rata-rata 76,67, artinya keterampilan komunikasi guru dalam pembelajaran pada siklus I masih berada dalam kategori cukup.

C. Refleksi

Kegiatan refleksi dilakukan secara kolaboratif antara peneliti dengan kepala sekolah pada saat FGD berakhir, dari hasil pengamatan yang dilakukan oleh observer, maka diketahui:

- Guru terlihat kurang nyaman dengan adanya FGD.

- Peneliti belum optimal menjangkau tujuan dan maksud pelaksanaan Focus Group Discussion (FGD)tentang pentingnya keterampilan komunikasi guru dalam proses pembelajaran.

- Hasil penilaian keterampilan komunikasi guru dalam proses pembelajaran siklus I belum menunjukkan hasil yang memuaskan, dimana nilai rata-rata keterampilan komunikasi guru adalah 76,67, artinya keterampilan komunikasi guru dalam proses pembelajaran di SD Negeri 06 Situjuah Gadang Kabupaten Lima Puluh Kota pada siklus I berada dalam kategori cukup.

Berdasarkan pengamatan, dan hasil penilaian maka tujuan yang diharapkan pada kegiatan Focus Group Discussion (FGD) siklus I belum tercapai. Dengan demikian upaya menerapkan Focus Group Discussion (FGD) untuk meningkatkan keterampilan komunikasi guru dalam pembelajaran akan ditargetkan pada siklus II. Rencana perbaikan ditargetkan pada kendala yang ditemui pada siklus I, dan akan dilaksanakan pada siklus II.

\section{Siklus II}

A. Rencana

Tahap perencanaan pada siklus II ini, peneliti melakukan pertemuan dengan observer, serta guru-guru untuk menyusun penjadwalan kembali Focus Group Discussion (FGD) dan menyiapkan instrument Focus Group Discussion (FGD) untuk siklus II.

B. Tindakan dan Pengamatan

Pada tahap ini, peneliti memonitoring dan mengamati guru-guru dalam teknik berkomunikasi dalam proses pembelajaran. Kegiatan Focus Group Discussion (FGD) menggunakan instrumen observasi, sesuai dengan rencana yang telah disusun sebelumnya. Pelaksanaan tindakan dilakukan sebagai berikut:

- Mengamati kemampuan guru dalam melakukan komunikasi pembelajaran di kelas dan menggunakan instrument pengamatan kemampuan berkomunikasi.

- Menganalisis kemampuan guru dalam melakukan komunikasi dalam pembelajaran.

- Melakukan tes kemampuan guru melakukan komunikasi dalam pembelajaran dengan dibimbing oleh peneliti.

- Melakukan diskusi dengan guru tentang hasil, proses pembelajaran yang dirasakan guru sehubungan dengan kemampuannya dalam berkomunikasi selama proses berlangsung.

Hasil dari observasi yang peneliti peroleh selama Siklus II terkait komunikasi guru dalam pembelajaran adalah sebagai berikut:

Tabel 3. Hasil Observasi Komunikasi Guru dalam Pembelajaran Siklus II

\begin{tabular}{|l|l|c|c|c|}
\hline No. & \multicolumn{1}{|c|}{ KARAKTERISTIK PENILAIAN } & Skor & $\begin{array}{c}\text { Skor } \\
\text { Maksimal }\end{array}$ & Kualifikasi \\
\hline 1. & Menggunakan bahasa yang baik & 3 & 4 & $\mathrm{~B}$ \\
\hline 2 & Menggunakan bahasa yang benar & 3 & 4 & $\mathrm{~B}$ \\
\hline 3 & Memilih kata yang gampang dipahami & 3 & 4 & $\mathrm{~B}$ \\
\hline 4 & Memilih kata yang tepat sasaran & 3 & 4 & $\mathrm{~B}$ \\
\hline 5 & Berbicara dengan tempo yang tepat & 3 & 4 & $\mathrm{~B}$ \\
\hline
\end{tabular}




\begin{tabular}{|l|l|c|c|c|}
\hline 6 & Tidak meyampaikan hal- hal yang kabur & 3 & 4 & B \\
\hline 7 & Berpikir logis & 4 & 4 & SB \\
\hline 8 & $\begin{array}{l}\text { Berbica untuk memotivasi kemampuan siswa } \\
\text { yang berbicara }\end{array}$ & 3 & 4 & B \\
\hline & Jumlah & $\mathbf{2 5}$ & $\mathbf{2 8}$ & \\
\cline { 2 - 5 } & Persentase & $\mathbf{8 9 , 3 \%}$ & & SB \\
\hline
\end{tabular}

Dari hasil lembaran pengamatan dapat dilihat jumlah skor yang diperoleh dalam pelaksanaan kegiatan FGD untuk meningkatkan keterampilan komunikasi guru dalam pembelajaran pada siklus II ini adalah 25 dan skor maksimalnya 28. Dengan demikian persentase skor rata-rata adalah 89,3\%. Berarti aktivitas selama kegiatan FGD berdasarkan hasil dari pengamatan observer berada pada kategori baik. Kegiatan FGD diakhiri evaluasi terhadap keterampilan komunikasi guru dalam pembelajaran.

Tabel 4. Hasil Penilaian Keterampilan Komunikasi Guru Dalam Pembelajaran Siklus II

\begin{tabular}{|c|c|c|c|c|c|c|c|}
\hline \multirow{2}{*}{ No } & \multirow{2}{*}{ Nama Guru } & \multicolumn{4}{|c|}{ ASPEK YANG DINILAI } & \multirow{2}{*}{ Jumlah } & \multirow{2}{*}{ Nilai } \\
\hline & & I & II & III & IV & & \\
\hline 1 & Maidar Soswati, S.Pd.SD & 4 & 4 & 4 & 5 & 17 & 85 \\
\hline 2 & Deswita, S.Pd.SD & 5 & 4 & 4 & 5 & 18 & 90 \\
\hline \multirow[t]{3}{*}{3} & Sri Pujianti, S.Pd.SD & 5 & 4 & 5 & 4 & 18 & 90 \\
\hline & Jumlah & & & & & & 265 \\
\hline & Rata-Rata & & & & & & 88,33 \\
\hline
\end{tabular}

Berdasarkan penilaian terhadap keterampilan komunikasi guru dalam pembelajaran yang dikemukakan tabel diatas terlihat nilai rata-rata kemampuan komunikasi guru dalam pembelajaran sudah mencapai rata-rata 88,33, artinya keterampilan komunikasi guru dalam pembelajaran pada siklus II sudah berada dalam kategori baik.

C. Refleksi

Kegiatan refleksi dilakukan secara kolaboratif antara peneliti dengan observer setiap tindakan FGD berakhir. Berdasarkan hasil kolaborasi diketahui bahwa pelaksanaan FGD untuk meningkatkan keterampilan komunikasi guru SD Negeri 06 Situjuah Gadang Kabupaten Lima Puluh Kota sudah dapat dikatakan berhasil. Pada siklus II ini, guru-guru sudah mampu melaksanakan komunikasi yang efektif dalam pembelajaran yang meliputi 4 kemampuan pokok, yaitu: 1) kemampuan guru mengembangkan sikap positif dalam kegiatan pembelajaran, 2) kemampuan guru untuk bersikap luwes dan terbuka dalam kegiatan pembelajaran, 3) kemampuan guru untuk tampil secara bersungguh-sungguh dalam kegiatan pembelajaran, dan 4) kemampuan guru untuk mampu mengelola interaksi siswa dalam kegiatan pembelajaran. Hal ini terlihat dari hasil penilaian keterampilan komunikasi guru dalam pembelajaran sudah mencapai nilai rata-rata 88,33. Dengan demikian tindakan Focus Group Discussion (FGD) untuk meningkatkan keterampilan komunikasi guru dalam proses pembelajaran sudah mencapai hasil yang diharapkan dan tidak perlu dilanjutkan ke siklus berikutnya.

Berdasarkan penjelasan yang telah dipaparkan sebelumnya secara keseluruhan dari hasil penelitian terdapat peningkatan maka terjadi pada hasil penilaian kemampuan komunikasi guru pada proses pembelajaran pada Siklus I dan Siklus II sebesar 11.66. Berikut grafik rekapitulasi kenaikan poin yang terjadi dari Siklus I ke Siklus II. 


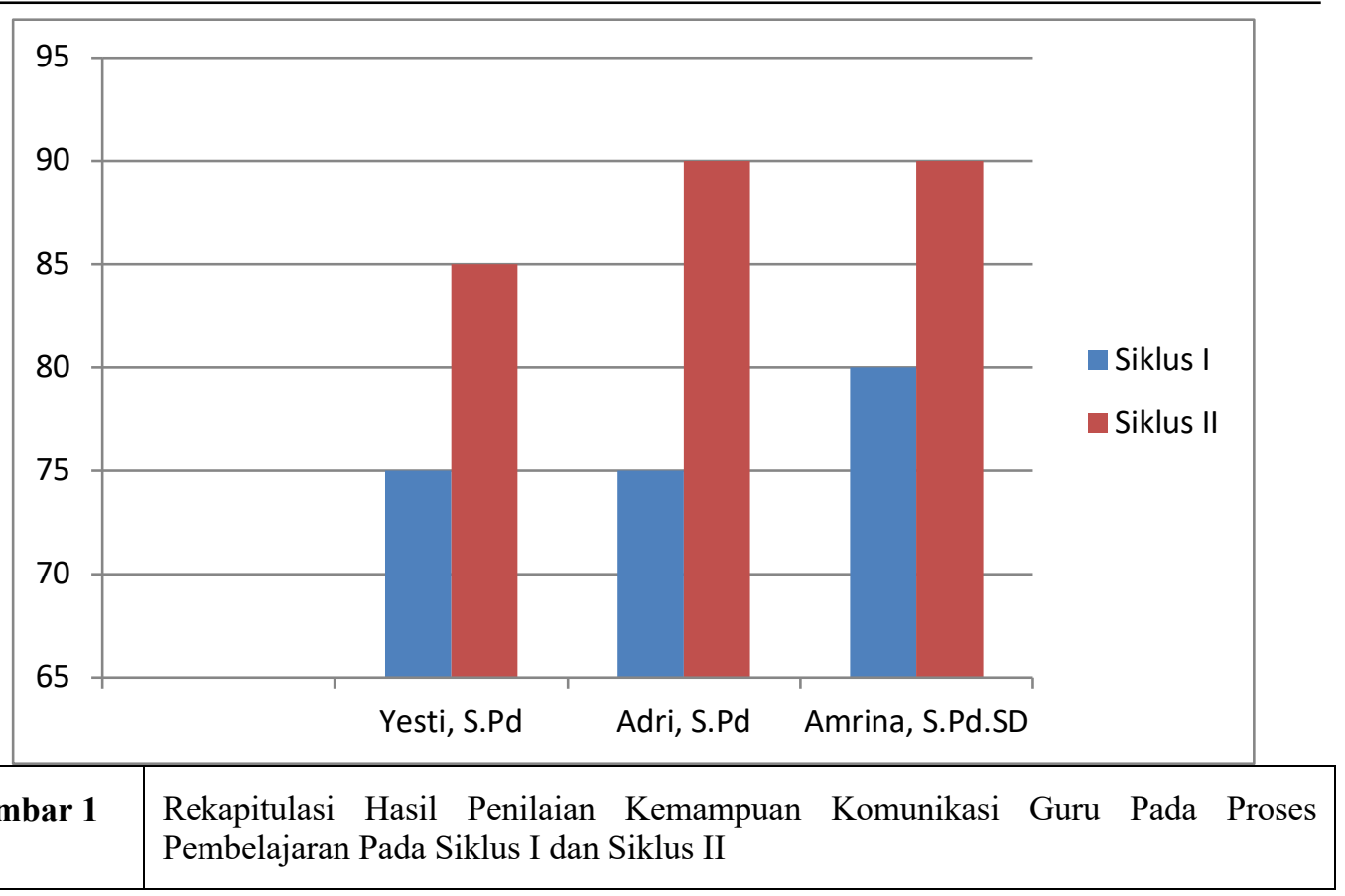

\section{PEMBAHASAN}

\section{Siklus I}

Berdasarkan hasil penelitian pada siklus I, terlihat bahwa keterampilan komunikasi guru SD Negeri 06 Situjuah Gadang Kabupaten Lima Puluh Kota dalam proses pembelajaran belum optimal. Walaupun telah dilaksanakan tindakan FGD, namun dari hasil lembaran pengamatan dapat dilihat keterampilan komunikasi guru dalam pembelajaran belum menunjukkan hasil yang memuaskan karena nilai rata-rata yang diperoleh baru mencapai 76,67 yang artinya keterampilan komunikasi guru di SD Negeri 06 Situjuah Gadang Kabupaten Lima Puluh Kota pada siklus I masih berada dalam kategori cukup.

Dari catatan hasil penilaian kemampuan guru dan diskusi peneliti dengan kepala sekolah sebagai kolaborator dan observer, ternyata guru memiliki kelemahan dalam memahami peranan penting komunikasi dalam pembelajaran.

Dari hasil penelitian dan tindakan FGD yang dilaksanakan, memperlihatkan keterampilan komunikasi guru dalam pembelajaran SD Negeri 06 Situjuah Gadang Kabupaten Lima Puluh Kota dari segi: 1) kemampuan guru mengembangkan sikap positif dalam kegiatan pembelajaran, 2) kemampuan guru untuk bersikap luwes dan terbuka dalam kegiatan pembelajaran, 3) kemampuan guru untuk tampil secara bersungguh-sungguh dalam kegiatan pembelajaran, dan 4) kemampuan guru untuk mampu mengelola interaksi siswa dalam kegiatan pembelajaran belum maksimal.

Merujuk kepada analisis penelitian siklus I yang belum mencapai hasil seperti yang diharapkan, peneliti merasa perlu merencanakan untuk melakukan siklus II dengan harapan lebih meningkatkan lagi keterampilan komunikasi guru SD Negeri 06 Situjuah Gadang Kabupaten Lima Puluh Kota dalam proses pembelajaran. Rencana perbaikan ditargetkan pada kendala-kendala yang ditemui pada siklus I, dan akan dilaksanakan pada siklus II.

\section{Siklus II}

Berdasarkan hasil penelitian pada siklus sebelumnya yang belum menunjukkan ketercapaian, dan setelah diadakan pengamatan dan refleksi bersama obeserver (kepala sekolah) maka tindakan Focus Group Discussion (FGD)dilanjutkan pada siklus II. Tindakan Focus Group Discussion (FGD)pada siklus II dilaksanakan berdasarkan hasil refleksi dan diskusi dari hasil Focus Group Discussion (FGD)pada siklus sebelumnya. Perencanaan tindakan dilakukan dengan lebih matang sehingga mampu tepat sasaran. Dengan perencanaan yang sangat baik, maka tindakan FGD untuk meningkatkan keterampilan komunikasi guru dalam pembelajaran pun menunjukkan hasil yang cukup memuaskan.

Berdasarkan catatan hasil dilapangan, observasi, dan diskusi dengan observer pada siklus II, dengan Focus Group Discussion (FGD)yang lebih menekankan pada pendekatan terhadap aspekaspek keterampilan komunikasi yang harus dikuasai guru, yakni keterampilan berbicara, 
keterampilan mendengar, dan keterampilan berkomunikasi secara non verbal. Berdasarkan penilaian terhadap keterampilan komunikasi guru dalam pembelajaran sudah mencapai nilai ratarata mencapai 88,33 artinya keterampilan komunikasi guru dalam pembelajaran pada siklus II meningkat dan berada dalam kategori baik. Guru-guru sudah memahami dan mampu menggunakan pendekatan komunikasi yang efektif.

Guru yang efektif menggunakan keterampilannya berkomunikasi dengan siswa, tetap kritis namun tidak berlebihan, lebih asertif daripada agresif, manipulatif ataupun pasif. Pola komunikasi guru dan siswa yang efektif akan sangat membantu dalam menyukseskan proses belajar mengajar.

\section{SIMPULAN DAN SARAN}

Berdasarkan hasil penelitian yang telah dipaparkan sebelumnya bahwa melalui Focus Group Discussion (FGD) dapat meningkatkan keterampilan komunikasi guru SD Negeri 06 Situjuah Gadang Kec. Situjuah Kab 50 Kota dalam proses pembelajaran. Hal ini dapat dilihat dari penilaian siklus II lebih tinggi dari pada hasil FGD siklus I yaitu dari niliai rata-rata 76,67 meningkat menjadi 88,33. Dengan demikian pelaksanaan FGD berhasil meningkatkan keterampilan komunikasi guru dalam pembelajaran. Lebih lanjut, pada perencanaan kegiatan FGD akademik harus disusun secara sistematis, sehingga tiap tahap kegiatan tidak tumpang tindih dan kegiatan Focus Group Discussion (FGD) berlangsung dengan baik.

\section{DAFTAR RUJUKAN}

Djamarah, dkk. 2000. Strategi Belajar Mengajar. Jakarta: Rineka Cipta.

Suherman, E. (2008). Model belajar dan pembelajaran berorientasi kompetensi siswa. Educare.

Paramita, A., \& Kristiana, L. (2013). Teknik Focus Group Discussion Dalam Penelitian Kualitatif. Buletin Penelitian Sistem Kesehatan, 16(2), 20840. 